\title{
$-a^{2}-$ \\ Historiography. Ethnology
}

удК: $930(450.341): 325.5: 338.121$

DOI: $10.26661 /$ zhv-2019-1-53-28

\section{A Historiographical Overview of Studies on the Venetian Tana from the Beginnings to the 2010s}

\author{
E. Khvalkov \\ National Research University Higher School of Economics, St. Petersburg \\ ekhvalkov@hse.ru \\ ORCID ID: https://orcid.org/0000-0003-3688-7638
}

Key words: Republic of Venice, Black Sea, Tana, Caffa, Sea of Azov, discussion, historiography, colonies.
This article offers a brief glance on the studies done on the history of the Venetian colony in Tana, in the embouchure of the River Don on the shores of the Sea of Azov. The study of the history of Italian trade on the Levant in general and in the areas of the Black Sea and the Sea of Azov in particular, including the Venetian colony in Tana, boasts a considerable historiographical tradition. The author, however, limits himself here to the classical studies and intentionally does not go beyond the year 2010. The scholars of the XIX early XX centuries laid down grounds for the scientific study of the Venetian trade and the development of its Black Sea colonies. To a certain extent the emergence of the social and economic history of the Levant and the Black Sea region were made possible thanks to the publication of sources. The authors of the first half of the XIX century, who studied this subject, were limited mainly to source studies, and even until now the study of history of the Italian presence on the Mediterranean and Black Seas in the XIII - XV centuries starts with a study of a range of unpublished archival sources. The early XX century was marked by intensive work on the identification and publication of the new sources. Some fundamental studies on the history of the Venetian politics and colonization in the Black sea were written. Further steps in the study of the Venetian expansion in the Black Sea area were made based on the materials of the Venetian archive. These projects tended to be collective and to be done in close relationship among the scholars from different countries. There appeared several studies on the history of the Venetian trading station in Tana. A number of researchers developed the problems of economic history of the region. The major problems of the Italian colonization were carefully studied in the recent decades. In the late XXth and early XXIst centuries there appeared a lot of studies of the Venetian and Genoese trading stations in the Black Sea and the Sea of Azov area, some of them were particularly focused exactly on Tana.

\section{Історіографічний огляд досліджень Венеціанської Тани від початку до 2010-х років}

\author{
Євген Хвальков
}

Національний дослідницький університет «Вища школа економіки», Санкт-Петербург
У статті пропонується короткий огляд досліджень, проведених з історії Венеціанської колонії в Тані, на березі Азовського моря. Вивчення історії італійської торгівлі на Леванте взагалі і в районах Чорного і Азовського морів зокрема, включаючи венеціанську колонію в Тані, може похвалитися значною історіографічною традицією. Автор, проте, обмежується тут класичними дослідженнями і навмисно не виходить за рамки 2010 року. 
Вчені XIX - початку XX століть заклали основи для наукового вивчення венеціанської торгівлі та розвитку ї̈ чорноморських колоній. Початок XX століття ознаменувався інтенсивною роботою з виявлення та публікації нових джерел. Подальші кроки у вивченні венеціанської експансії в Причорномор'ї були зроблені на основі матеріалів Венеціанського архіву. Основні проблеми італійської колонізації були ретельно вивчені в останні десятиліття. В кінці XX - початку XX століття $3^{\prime}$ явилося багато досліджень венеціанських і генуезьких торгових станцій в районі Чорного і Азовського морів, деякі з них були особливо зосереджені саме на Тані.

This short paper is not intended to be comprehensive, but rather offers a brief glance on the studies done on the history of the Venetian colony in Tana, in the embouchure of the River Don on the shores of the Sea of Azov. The study of the history of Italian trade on the Levant in general and in the areas of the Black Sea and the Sea of Azov in particular, including the Venetian colony in Tana, boasts a considerable historiographical tradition. The author, however, limits himself here to the classical studies and intentionally does not go beyond the year 2010 .

The history of the Black Sea commerce and of the Italian (chiefly Genoese and Venetian) colonization of the region implying the establishment of the new settlements provoked interest already starting from the XVI century, because it was impossible to write the historical narratives on Venice without covering also its trade and it colonial possessions in the Mediterranean Sea and in the Black Sea area. However, the authors of the early modern historical narratives highlighted the events of the political life of their city-state, outlined the nature of trade, linked economic, diplomatic and military policy, but did not turn to the study of economic life and economic and social history as such. The problems of the Mediterranean economy and society came to the attention of the historians much later - they took a significant place in historical scholarship only in the XIX century, together with the emergence of economic and social history as disciplinary fields of historical science and the beginning of scientific critical study of sources.

The scholars of the XIX - early XX centuries laid down grounds for truly scientific study of the Venetian trade and the development of its Black Sea colonies. To a certain extent the emergence of the social and economic history of the Levant and the Black Sea region were made possible thanks to the publication of sources. With regard to Venice, the most famous publication of this type is the one by G. L. F. Tafel and G. M. Thomas ${ }^{1}$ ). In addition, a

1 Urkunden zur alteren Handels- und Staatsgeschichte der Republik Venedig mit besonderer Beziehung auf Byzanz und die Levante om 9. bis zum Ausgang des 15. Jahrh. herausg. von G. L. Fr. Tafel und G. M. Thomas, Vienne 1856-57; Diplomatarium number of sources of Genoese origin related to the Genoese colonies in the East had been published by A. Vigna ${ }^{2}$. The authors of the first half of the XIX century, who studied this subject, were limited mainly to source studies. One of the first generalizing studies that considered the issues of Venetian trade (including the Black Sea trade) was the monograph written by Pierre Antoine Noël Bruno, count Daru ${ }^{3}$. Another major achievement in the study of the Mediterranean trade of Venice was the two-volume classic work of the German scientist W. Heyd «History of medieval Levantine trade», published in German ${ }^{4}$ and in French ${ }^{5}$. Long before the «History» Heyd also published a book about the Italian trading stations of in the East ${ }^{6}$. It was one of the first overviews of this subject in Italian and his study was extremely appreciated and recognized by the Italian colleagues and was included in the publication of the "Nuova collezione di opere storiche". Heyd became one of the founders of the scientific study of the Mediterranean trade in the middle ages, and his works served as the basis for subsequent researchers of this subject and are recognized to this day. One can say that this monograph is unsurpassed in terms of the breadth of coverage and preciseness of the source data. Heyd used in his «History» a wide range of sources published by the time, and he was consequently the first one who gave a more or less description of the Venetian trading station of the Black Sea region. Publishing his «History», Heyd confessed that outside of the work of G.-G. Depping ${ }^{7}$

Veneto-Levantinum, sive Acta et Diplomata res venetas atque levantis illustrantia. Pars I / Ed. G. M. Thomas. Venetiis, 1880; Pars II / Ed. R. Predelli. Venetiis, 1899.

2 Vigna A. Codice diplomatico delle colonie tauro-liguri durante la signoria dell'Ufficio di San Giorgio $(1453$ - 1475) // ASLSP. Genova, 1868 - 1879. V. VI - VII.

3 Daru P. Histoire de la Republique de Venise. Seconde édition, revue et corrigée. T. I - VIII. Paris, 1821.

4 Heyd W. Geschichte des Levantehandels im Mittelalter. Stuttgart, 1879.

5 Heyd W. Histoire du commerce du Levant au moyen âge. Leipzig, 1885.

6 Heyd Gugl. Le colonie commerciali degli Italiani in Oriente nel medio evo, dissertazioni del prof. Gugl. Heyd, recata in italiano dal prof. Gius. Müller. Venezia e Torino, 1866 - 1868.

7 Depping G.-B.. L'Histoire du commerce entre le Levant et 
he had almost no one to refer to as his predecessor. All the other authors whom he mentions were mainly the source publishers. Until now the study of history of the Italian presence on the Mediterranean and Black Seas in the XIII - XV centuries begins with a study of a range of unpublished archival sources.

The activity of the Odessa Society for History and Antiquities (300ИД) founded in 1839 contributed greatly to the study of sources. For example, the materials on the management of the Genoese Gazaria by the Bank of Saint George were studied by Russian historians in this society, as well as the work of the Tauric Scientific Archive Commission (ИТУАК) and other institutions ${ }^{8}$. The merits of their scholars in the field of the study of the history of the Black Sea in the middle ages were widely recognized ${ }^{9}$. The major scholars working within these institutions on the history of Italian politics and colonization in the Black sea were F. K. Brun ${ }^{10}, \mathrm{M}$. Volkov $^{11}$, V. N. Yurgevich ${ }^{12}$, and L. P. Kolly ${ }^{13}$, who were

l'Europe. Paris, 1830. 2 vol.

8 Мурзакевич Н. Донесение об осмотре архива Банка Св. Георгия // 300ИД, Т. 5. Одесса, 1863. С. 982 - 985.

9 Мурзакевич Н. Филипп Карлович Брун // З00ИД, Т. 12. Одесса, 1881. С. $443-446$.

10 Брун Ф. К. 0 поселениях итальянских в Газарии. М., 1872; Он же. Черноморье. Одесса, 1879 - 1880. Ч. 1, 2; 0н же. Etudes sur le commerce au moyen-âge. Histoire du commerce de la mer Noire et des colonies Génoises de la Krimée / Par F. de la Primandaie // З00ИД, Т. 2. Одесса, 1848. С. 709 - 718; Он же. Восточный берег Черного моря по древним периплам и по компасовым картам // 300ИД, Т. 9. Одесса, 1875. С. 410 - 428; 0н же. Древняя топография некоторых мест Новороссийского края и Бессарабии. Б. г.; Он же. Материалы для истории Сугдеи. Одесса, 1871; 0н же. Одесское общество истории и древностей, его записки и археологические собрания. Одесса, 1870; Брун Ф. К. Рецензия на: Обмеление Азовского моря. Приложение к Морскому Сборнику. СПб., 1861 // З00ИД, Т. 5. Одесса, 1863. С. 966 - 973; Он же. Черноморские готы и следы долгого их пребывания в Южной России. СПб., 1874.

11 Волков М. 0 соперничестве Венеции с Генуей в XIV в. // 300ИД. 1860. Т. 4. С. $151-236 ; 0$ н же. Четыре года города Каффы (1453, 1454, 1455 и 1456) // З00ИД, Т. 8. Одесса, 1872. C. $109-144$.

12 Устав для генуэзских колоний в Черном море, изданный в Генуе в 1449 г. / Латинский текст с переводом и примечаниями; изд. В. Н. Юргевич // З00ИД. Одесса, 1863. T. V. С. $629-837$; Юргевич В. Генуэзская надпись, найденная в Феодосии в 1883 году // З00ИД, Т. 14. Одесса, 1888. С. 24 - 26; Он же. Генуэзские надписи в Крыму // 300ИД, Т. 5. Одесса, 1863. С. 157 - 177; Он же. Две генуэзские надписи из Балаклавы // З00ИД, Т. 11. Одесса, 1879. С. 319 - 320; 0н же. Замечания на статью о Генуэзских монетах, помещенную в VIII томе Записок Общества, сделанные итальянским ученым К. Десимони // З00ИД, Т. 8. Одесса, 1872. С. 465 - 471; 0н же. Новые надписи Генуэзские // 300ИД, Т. 7. Одесса, 1868. С. $274-281$.

13 Колли Л. П. Каффа в период владения Банком св. Георгия // ИтУАК. 1912. Т. 47. С. $75-112$. Он же. П. Исторические an integral part of the European science, thus, ITUAK published translations of foreign scientists ${ }^{14}$. Also, there was a long-standing historiographical tradition in cartography ${ }^{15}$ and epigraphic ${ }^{16}$; the latter is especially important for the dating of coTsulates and the time of construction of buildings in the colonies, which cannot always be restored based on the written sources. There were equally thoroughly studies in numismatics ${ }^{17}$, and the Golden Horde coins with a mark of Caffa attracted

документы о падении Каффы // ИТУАК, №45 (год двадцать пятый). Симферополь, 1911. С. 1 - 24; Он же. 06 одном генуэзском барельефе Феодосийского музея (с рисунками) // ИТУАК, №53 (год двадцать девятый). Симферополь, 1916. С. 147 - 151; Он же. Падение Каффы // ИТУАК, №54 (год тридцать первый). Симферополь, 1918. С. 129 - 171; 0н же. Хаджи-Гирей хан и его политика (по генуэзским источникам). Взгляд на политические сношения Каффы с татарами в XV веке // ИТУАК, №50 (год двадцать шестой). Симферополь, 1913. С. $99-139$.

14 Извлечение из сочинений Вильгельма Гейда «История торговли Востока в средние века (Колонии на северном побережье Черного моря. Конец западных колоний северного побережья Черного моря)». Перевод Л. П. Колли // ИТУАК, №52 (год двадцать восьмой). Симферополь, 1915. C. $68-185$.

15 Брун Ф. К. Восточный берег Черного моря по древним периплам и по компасовым картам // З00ИД, Т. 9. Одесса, 1875. С. 410 - 428; Бертье-Делагард А. Л. К вопросу о местонахождении Маврокастрона Записки готского топарха // 300ИД, Т. 33. Одесса, 1916. С. 1 - 20; Разные замечания, касательные до острова Таманя // З00ИД, Т. 10. Одесса, 1877. C. $230-234$.

16 Юргевич В. Генуэзские надписи в Крыму // 300ИД, Т. 5. Одесса, 1863. С. 157 - 177; 0н же. Новые надписи Генуэзские // 300ИД, Т. 7. Одесса, 1868. С. 274 - 281; 0н же. Две генуэзские надписи из Балаклавы // З00ИД, Т. 11. Одесса, 1879. С. 319 - 320; 0н же. Генуэзская надпись, найденная в Феодосии в 1883 году // З00ИД, Т. 14. Одесса, 1888. С. 24 - 26; 0н же. 06 археологических разысканиях и открытиях в Южной России, предшествовавших учреждению Одесского Общества истории и древностей // 300ИД, Т. 14. Одесса, 1888. С. 27 - 51; Кочубинский А. Лапидарные надписи XV столетия из Белгорода, что ныне Аккерман // 300ИД, Т. 15. Одесса, 1889. С. 506 - 547; Ретовский 0. Ф. Генуэзские надписи, найденные в г. Феодосии в 1894 г // З00ИД, Т. 19. Одесса, 1896. С. $14-26$.

17 Мурзакевич Н. Медные монеты города Каффы // З00ИД, Т. 4. Одесса, 1860. С. 387 - 388; Юргевич В. 0 монетах Генуэзских, находимых в России // З00ИД, Т. 8. Одесса, 1872. С. 147 - 166; 0н же. Замечания на статью о Генуэзских монетах, помещенную в VIII томе Записок Общества, сделанные итальянским ученым К. Десимони // 300ИД, Т. 8. 0десса, 1872. С. 465 - 471; Юргевич В. 0 монетах Генуэзских, находимых в России // З00ИД, Т. 8. Одесса, 1872. С. 147 - 166; 0н же. Замечания на статью о Генуэзских монетах, помещенную в VIII томе Записок Общества, сделанные итальянским ученым К. Десимони // З00ИД, Т. 8. Одесса, 1872. С. 465 - 471; Опимах 0. Г. Коллекция генуэзскотатарских аспров в собрании национального заповедника «София Киевская» // Сугдейский сборник, вып. II. Киев; Судак, 2005. С. 527. 
special attention of the researchers of the XIX - XX centuries ${ }^{18}$. These Genoese-Tatar coins were studied by 0 . Retovsky ${ }^{19}$. The contemporary historiography connects these marks on the Golden Horde coins with the Caffiote mint. These coins are seen as a transitional stage between the Golden Horde coins minted in Caffa at the beginning of the XV century and the aspres of Caffa of the $1420-1470$ s. $^{20}$ The coins with the Tatar tamga were widely produced in the $1370-1380 \mathrm{~s}^{21}$ and widely spread in $\mathrm{Azaq}^{22}$. Nowadays there are different opinions on the starting point of the own coinage of the Genoese Caffa as well as on the marks ${ }^{23}$, but it is clear that these coins served both to the needs of the local market and to the intense exchanges between the Crimean trading stations of Genoa and Tana. The numismatic material was analyzed both from the point of view of the information on the political history that it provides, and, subsequently, from the point of view of the history of the economy and monetary circulation in the region in the middle ages ${ }^{24}$.

The early XX century was marked by intensive work on the identification and publication of the new sources. Some fundamental studies on the history of the Venetian politics and colonization in the Black sea were written by F. Brun, M. Volkov, and N.

18 Ретовский 0. Ф. Генуэзско-татарские монеты города Каффы // ИТУАК, №27 (год одиннадцатый). Симферополь, 1897. С. 49 - 104; 0н же. Генуэзско-татарские монеты города Каффы // ИТУАК, №29 (год двенадцатый). Симферополь, 1899. С. 1 - 52; Он же. Генуэзско-татарские монеты города Каффы // ИТУАК, №32 - 33 (год шестнадцатый). Симферополь, 1902. С. 1 - 17; 0н же. Генуэзско-татарские монеты (с 1 табл.) // ИТУАК, том 51 (1914 г.). С. 1 - 16; 0н же. Генуэзско-татарские монеты (с 6 табл.). ИТУАК, Т. 18 (1906). 1 - 72; Григорьев, В. Монеты Джучидов, генуэзцев и Гиреев, битые на Таврическом полуострове и принадлежащие Обществу // 300ИД, Т. 1. Одесса, 1844. С. $301-314,654$.

19 Ретовский 0. Ф. Генуэзско-татарские монеты города Каффы // ИТУАК, №29 (год двенадцатый). Симферополь, 1899. C. 51.

20 Еманов А. Г. Север и Юг в истории коммерции на материалах Каффы XIII - XV вв. Тюмень, 1995. С. 111.

21 Козубовский Г. А. 0 времени появления Каффинских надчеканок на джучидских монетах // Сугдейский сборник, вып. II. Киев; Судак, 2005. С. 156.

22 Фомичев Н. М. Джучидские монеты из Азова // СА. 1981. № 1. С. $225,239$.

23 Козубовский Г. А. 0 времени появления Каффинских надчеканок на джучидских монетах // Сугдейский сборник, вып. ІІ. Киев; Судак, 2005. С. 155.

24 Федоров-Давыдов Г. А. Денежно-весовые единицы Таны в начале XIV в. (по данным Франческо Пеголотти) // СА. 1958. N 3. С. 65 - 72; Пономарев А. Л. Денежный рынок Трапезундской империи в XIII - XV вв. // Причерноморье в средние века / Под ред. С. П. Карпова. Вып. 3. СПб., Алетейя, 1998. С. 201 - 239. Он же. Эволюция денежных систем Причерноморья и Балкан в XIII - XV вв. Автореф. дисс... докт. ист. наук. М., 2010.
Murzakevich. Moreover, M. M. Kovalevsky published two essays about Tana ${ }^{25}$, which served as a preparatory material for his three-volume work on the economic growth of Europe. Besides that, he was the author of the work «0n Russian and other Orthodox slaves in Spain», where he argued based on a large number of sources and convincingly proved that the Orthodox slaves got to Spain through Europe from coast of the Black sea ${ }^{26}$ (the conclusions were largely based on his paper given in $1884^{27}$ ). Finally, one should mention panoramic studies by A. K. Dzhivelegov ${ }^{28}$ and I. N. Kulisher ${ }^{29}$, discussing the general problems of medieval trade.

Further steps in the study of the Venetian expansion in the Black Sea area were made by N. Iorga based on the materials of the Venetian archive ${ }^{30}$. His successor, G. Bratianu, contributed a lot to the study of political and economic history of the areas which were under the Venetian influence ${ }^{31}$. In the postwar period there appeared a generalizing panoramic study on the history of the Italian economy by Gino Luzzatto ${ }^{32}$ and a study on the sources for the history of Italian trade by Federigo Melis ${ }^{33}$. One should also note the work of the Institute of medi-

25 Ковалевский М. М. К ранней истории Азова. Венецианская и генуэзская колонии в Тане в XIV веке // Труды XII Археологического съезда в Харькове, 1902. М., 1905. Т. 2. С. 143 - 144. Этой статье предшествовал доклад на ту же тему. 0 М. М. Ковалевском см. также: Матиева А. Х. История итальянских факторий Северного Причерноморья в рукописях и трудах М. М. Ковалевского // Причерноморье в средние века / Под ред. С. П. Карпова. Вып. 7. М.; СПб., 2009. С. $238-378$.

26 Ковалевский М. М. 0 русских и других православных рабах в Испании // Юридический вестник. М., 1886. Вып. 2. C. $238-254$.

27 Шестой Археологический съезд в 0дессе 1884 // Труды VI Археологического съезда в Одессе. Одесса, 1886. Т. 1. С. 27, 65 - 66; Ковалевский М. М. Шестой Археологический съезд в Одессе // Вестник Европы. 1884. Кн. 12. С. 842.

28 Дживелегов А. К. Торговля на Западе в Средние века. СПб., 1904.

29 Кулишер И. Н. Эволюция прибыли с капитала в связи с развитием промышленности и торговли в Западной Европе. Т. 1. СПб., 1906.

30 Iorga $\mathrm{H}$. Notes et extraits pour servir à l'histoire des Croisades au XVe siècle // ROL. T. 4 - 8. 1896 - 1900. Также работа, посвященная Тане: Iorga N. Un viaggio da Venezia alla Tana // NAV. 1896. T. XI. P. 5 - 13.

31 Brătianu G. Recherches sur le commerce Génois dans la Mer Noire au XIIIe siècle. Paris, 1929; Idem. La Mer Noire. Des origines à la conquête ottomane.München, 1969; Idem. Les Vénitiens dans la Mer Noire au XIVe siècle après la deuxième guerre de Détroits // E0. 1934. N 174. P. 148 - 162; Idem. Les Vénitiens dans la Mer Noire au XIVe siècle. La politique du Sénat en 1332-33 et la notion de Latinité. Bucureşti, 1939.

32 На русском: Луццато Дж. Экономическая история Италии. Античность и средние века. М., 1954.

33 Melis F. Documenti per la storia economica dei secoli XIII XVI. Firenze, 1972. 
eval studies of the University of Genoa, established in 1963 and headed by Geo Pistarino. Pistarino and his students studied mainly the problems of economic history. These projects tended to be collective and to be done in close relationship among the scholars from different countries.

The major problems of the Italian colonization were carefully studied by F. Thiriet and M. Balard. In F. Thiriet's monograph the emphasis was placed on consideration of the Mediterranean possessions of Venice $^{34}$. Thiriet also investigated certain aspects of Venetian trade in the Black Sea region, to which he returned in his subsequent publications, using the materials of the Venetian assemblies, regestae which he had previously compiled. M. Balard made the greatest contribution to the study after V. Heyd in his classical monograph on the Genoese colonies ${ }^{35}$. The economy and trade of Venice in the middle ages, navigation, money circulation, and market conditions were actively studied by F. Lane ${ }^{36}$ and R. Muller ${ }^{37}$. Slavery and the slave trade were studied by a Belgian schol$\operatorname{ar} \mathrm{Ch}$. Verlinden ${ }^{38}$. There appeared several studies on the history of the Venetian trading station in Tana ${ }^{39}$. A number of researchers developed the problems of economic history of the region ${ }^{40}$. M. Nystazopoulou-Pele-

34 Thiriet F. La Romanie Vénitienne au moyen âge. Paris, 1959. 35 Balard M. La Romanie Génoise (XIIe - début du XVe siècle). Roma - Genova, 1978. T. I - II; Idem. The Greeks of Crimea under Genoese Rule in the XIVth and XVth Centuries // Dumbarton Oaks Papers, Vol. 49, Symposium on Byzantium and the Italians, 13th - 15th Centuries, 1995 P. 23 - 32; Idem. Les Orientaux à Caffa au XVe siècle // Byzantinische Forschungen, T. 11, 1987. P. 223 - 238. 36 Lane F., Mueller R. C. Money and banking in Medieval and Renaissance Venice. Baltimore; London, 1985. Vol.1; Lane F. C. Le Navi di Venezia. Torino, 1983; Lane F. C. Venice and History. Baltimore, 1966. Lane F. C. Venice: A Maritime Republic. Baltimore; London, 1973.

37 Mueller Reinhold C. The Venetian Money Market; Banks, Panics and the Public Debt, 1200-1500. Baltimore/London: Johns Hopkins Press, 1997; Lane F., Mueller R. C. Money and banking in Medieval and Renaissance Venice. Baltimore; London, 1985. Vol. 1. 38 Verlinden Ch. La colonie venetienne de Tana, centre de la traite des esclaves au XIVe et au début du XVe siècle // Studi in onore di Gino Luzzatto. Milano, 1950, vol. 2, P. 1 - 25; Idem. L'esclavage dans l'Europe médiévale. T. 2: Italie. Colonie italiennes du Levant latin. Empire Byzantin. Gent, 1977; Idem. Esclaves et etnographie sur les bords de la Mer Noire (XIIIe et XIVe siècles) // Miscellanea historica in honorem L. van der Essen. Bruxelles - Paris, 1947; Idem. Le commerce en Mer Noire // XIII Congress International des sciences historiques. Moscou, 1970.

39 Berindei M., Veinstein G. La Tana-Azaq de la présence italienne à l'emprise ottomane (fin XIIIe - milieu XVIe siècle), «Turcica», 1976, T. VIII / 1 / P. 110 - 201; Doumerc B. Les Venetiens à la Tana // Le Moyen Age. 1988. T. 94. num. 3 - 4. P. 363 - 379; Idem. La Tana au XVe siècle // Etat et colonisation au Moyen Age et à la Renaissance. Lyon, 1989, P. $251-266$. 40 Laiou-Thomadakis A. E. The Byzantine Economy in the Mediterranean Trade System, Thirteenth - Fifteenth Centuries // DOP, 1980 - 1981, vol. 34 / 35, P. 177 - 222; Fleet K. European kides summarized the presence of the Venetians on the Black sea ${ }^{41}$. A study on the baiulatus of Venice in Constantinople and on the Venetian administrative system was carried out by Ch. Maltezou ${ }^{42}$. M. Martin argued in favor of the theory of the penetration of the Venetian merchants to the Black Sea before the XIII century ${ }^{43}$. Donald Nicol gave in his panoramic study ${ }^{44}$ a detailed description of the relations between Venice and Byzantium from the beginnings of the Venetian Republic to the fall of the Byzantine Empire. His study is a generalizing one; it often does not have a deep analysis of the socio-economic causes of certain processes, but it is highly informative as for the history of international relations in the middle ages.

In the late XXth and early XXIst centuries there appeared a lot of studies of the Venetian and Genoese trading stations in the Black Sea and the Sea of Azov area (some of them were particularly focused exactly on Tana): here it is necessary to mention the studies by S.P. Karpov ${ }^{45}$, A.L. Ponomarev ${ }^{46}$, A.A.

and Islamic Trade in the Early Ottoman State: the Merchants of Genova and Turkey. Cambridge University Press, 1999.

41 Nystazopoulou-Pelekides M. Venise et la Mer Noire du XIe au XVe siècle // Thesaurismata. 1970. Vol. 7. P. 15 - 51.

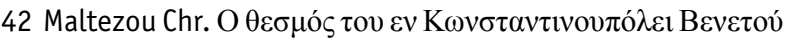
ßaї̀ ov (1268 - 1453). Athenai, 1970.

43 Martin C. A. Venetian Tana // Byzantinische Forschungen, Bd. XI. Amsterdam, 1980.

44 Nicol D. Byzantium and Venice: a study in diplomatic and cultural relations. Cambridge University Press, Cambridge, 1988. 45 Карпов С. П. Древнейшие постановления Сената Венецианской республики о навигации в Черном море // Причерноморье в средние века / Под ред. С. П. Карпова. Вып. 4. СПб., 2000. С. 11 - 18; Он же. Документы по истории венецианской фактории Тана во второй половине XIV в. // Причерноморье в средние века / Под ред. С. П. Карпова. Вып. 1. М., 1991. С. 191 - 216; 0н же. Венецианская Тана по актам канцлера Бенедетто Бьянко (1359-60гг.) // Причерноморье в средние века. Вып. 5. М.; СПб, 2001. С. 9 26; 0н же. Кризис Таны 1343 г. в свете новых источников. // BB.1994. T. 55 (80). Ч. 1. C. 121 - 126; Karpov S. P. Génois et Byzantins face à la Crise de Tana de 1343 d'après les documents d'archives inédits // Byzantinische Forschungen. 1996. Bd. XXII. P. 33 - 51; Idem. Le comptoir de Tana comme le centre des rapports économiques de Byzance avec la Horde d'Or aux XIIIe - XVe siècles // Byzantinische Forschungen. 1999. Bd. XXV. S. 181 - 188; Idem. Orthodox Christians in Italian-Tartar surrounding. New Archival Evidences on Rich and Poor in Venetian Tana, XIVth - XVth Centuries // Ricchi e Poveri nella Societ dell'Oriente Grecolatino. Simposio Internazionale / A cura di Chryssa A. Maltezou. Venezia, 1998. P. 453 - 472; Idem. Venezia e Genova: rivalità e collaborazione a Trebisonda e Tana, secoli XIII - XV // Genova, Venezia, il Levante nei secoli XII - XIV. Atti del Convegno Internazionale di Studi, Genova - Venezia, 10 - 14 marzo 2000 / A cura di G. Ortalli - D. Puncuh. Venezia, 2001. P. 257 - 272; Idem. On the Origin of medieval Tana // STEFANOS. Studia byzantina ac slavica Vladimíro Vavř́nek dedicata. BS, LVI/1. 1995. P. 227 - 235.

46 Пономарев А. Л. Монетное обращение Золотой Орды в XIV в. (методика анализа) // Причерноморье в средние века 
Talyzina ${ }^{47}$, N.D. Prokofieva ${ }^{48}$ and others. The monograph of S. P. Karpov devoted to the Italian maritime republics and the Southern Black Sea coast in the XIII - XV centuries ${ }^{49}$ is the first fundamental generalizing work focusing on one of the main directions of the trade of Genoa and Venice in the Southern Black Sea region. The monograph is particularly valuable because it is based on a wide range of sources, both published and unpublished. The second chapter of the monograph describes the structure of the Venetian trade carried out through the ports of the Black Sea region, connecting the West with the East. The author reconsidered in this book the vision of the relative shares of the groups of the imported and exported commodities within the general structure of both local and international trade ${ }^{50}$. Scrutinizing the balance of the Italian maritime republics, S. P. Karpov came to the conclusion that the steady deficit of gold and silver in their trade with the Southern Black Sea region was fully compensated by the profits from resale of goods delivered to Western Europe ${ }^{51}$. The monograph of S.P. Karpov demonstrated the scrupulous analysis of sources and filled many gaps, it was also important for the study of the political history of the Northern Black Sea region. In another monograph S. P. Karpov studied the Black Sea navigation of the Venetian Republic in the XIII - XV centuries $^{52}$ : the types of ships and conditions of seafare, piracy, routes of navigation, composition of crews etc. The monograph was published with tables and graphs with all the main parameters of navigation, which was an accurate barometer of the state of trade relations in the region. Another monograph

/ Под ред. С. П. Карпова. Вып. 2. М., 1995. С. 131 - 155; Он же. Деньги Золотой Орды и Трапезундской империи. Квантитативная нумизматика и процессы средневековой экономики. М., 2002; 0н же. Эволюция денежных систем Причерноморья и Балкан в XIII - XV вв. Автореф. дисс... докт.ист.наук. М., 2010.

47 Талызина А. А. Венецианский нотарий в Тане Кристофоро Риццо (1411 - 1413) // Причерноморье в средние века / Под ред. С. П. Карпова. Вып. 4. СПб., 2000. С. 19 - 35; Она же. Венецианские нотариальные акты: новые возможности старых источников. // Byzantinoslavica. 1999. Vol. LX/2, P. $459-468$.

48 Прокофьева Н. Д. Акты венецианского нотария в Тане Донато а Мано (1413 - 1419) // Причерноморье в средние века / Под ред. С. П. Карпова. Вып. 4. СПб., 2000. С. 36 - 174. 49 Карпов С. П. Итальянские морские республики и Южное Причерноморье в XIII - XV вв. М., 1990.

50 Карпов С. П. Итальянские морские республики... С. 45. 51 Карпов С. П. Итальянские морские республики... С. 72. 52 Карпов С. П. Путями средневековых мореходов: Черноморская навигация Венецианской республики в XIII XV вв. М., 1994. Также см. итальянское издание: Karpov S. P. La Navigazione Veneziana nel Mar Nero XIII - XV sec. Ravenna, 2000. by S.P. Karpov on the history of the Trebizond Empire ${ }^{53}$ was focused on the political and economic relations in the Eastern Mediterranean and the Black Sea region in the XIII - XV centuries, stressing for the first time in modern historiography the international importance of the Trebizond state in the middle ages, its role as a mediator between Europe and the Middle East.

Here the author stops, as the overview of the most recent historiography of the last decade was not set as a goal in this article; however, much was done and still much has to be done, including a panoramic generalizing history of Tana, and remains a matter of future. 


\section{LITERATURE}

Balard M. La Romanie Génoise (XIIe - début du XVe siècle). Roma - Genova, 1978. T. I - II.

Balard M. Les Orientaux à Caffa au XVe siècle // Byzantinische Forschungen, T. 11, 1987. P. 223 - 238.

Balard M. The Greeks of Crimea under Genoese Rule in the XIVth and XVth Centuries // Dumbarton Oaks Papers, Vol. 49, Symposium on Byzantium and the Italians, 13th - 15th Centuries, 1995 P. 23 - 32.

Berindei M., Veinstein G. La Tana-Azaq de la présence italienne à l'emprise ottomane (fin XIIIe - milieu XVIe siècle), «Turcica», 1976, T. VIII / 1 / P. $110-201$.

Brătianu G. La Mer Noire. Des origines à la conquête ottomane.München, 1969.

Brătianu G. Les Vénitiens dans la Mer Noire au XIVe siècle après la deuxième guerre de Détroits // E0. 1934. N 174. P. $148-162$.

Brătianu G. Les Vénitiens dans la Mer Noire au XIVe siècle. La politique du Sénat en 1332-33 et la notion de Latinité. Bucureşti, 1939.

Brătianu G. Recherches sur le commerce Génois dans la Mer Noire au XIIIe siècle. Paris, 1929.

Daru P. Histoire de la Republique de Venise. Seconde édition, revue et corrigée. T. I - VIII. Paris, 1821.

Depping G.-B.. L'Histoire du commerce entre le Levant et l'Europe. Paris, 1830. 2 vol.

Diplomatarium Veneto-Levantinum, sive Acta et Diplomata res venetas atque levantis illustrantia. Pars I / Ed. G. M. Thomas. Venetiis, 1880; Pars II / Ed. R. Predelli. Venetiis, 1899.

Doumerc B. La Tana au XVe siècle // Etat et colonisation au Moyen Age et à la Renaissance. Lyon, 1989, P. 251 - 266.

Doumerc B. Les Venetiens à la Tana // Le Moyen Age. 1988. T. 94. num. 3 - 4. P. 363 - 379.

Fleet K. European and Islamic Trade in the Early Ottoman State: the Merchants of Genova and Turkey. Cambridge University Press, 1999.

Heyd Gugl. Le colonie commerciali degli Italiani in Oriente nel medio evo, dissertazioni del prof. Gugl. Heyd, recata in italiano dal prof. Gius. Müller. Venezia e Torino, 1866 - 1868.

Heyd W. Geschichte des Levantehandels im Mittelalter. Stuttgart, 1879.

Heyd W. Histoire du commerce du Levant au moyen âge. Leipzig, 1885.

Iorga N. Un viaggio da Venezia alla Tana // NAV. 1896. T. XI. P. 5 - 13.

Iorga H. Notes et extraits pour servir à l'histoire des Croisades au XVe siècle // ROL. T. 4 - 8. $1896-1900$.

Karpov S. P. Génois et Byzantins face à la Crise de Tana de 1343 d'après les documents d'archives inédits // Byzantinische

Forschungen. 1996. Bd. XXII. P. 33 - 51.

Karpov S. P. La Navigazione Veneziana nel Mar Nero XIII - XV sec. Ravenna, 2000.

Karpov S. P. Le comptoir de Tana comme le centre des rapports économiques de Byzance avec la Horde d'Or aux XIIIe XVe siècles // Byzantinische Forschungen. 1999. Bd. XXV. S. 181 - 188.

Karpov S. P. Orthodox Christians in Italian-Tartar surrounding. New Archival Evidences on Rich and Poor in Venetian Tana, XIVth - XVth Centuries // Ricchi e Poveri nella Società dell'Oriente Grecolatino. Simposio Internazionale / A cura di Chryssa A. Maltezou. Venezia, 1998. P. 453 - 472.

Karpov S. P. Venezia e Genova: rivalità e collaborazione a Trebisonda e Tana, secoli XIII - XV // Genova, Venezia, il Levante nei secoli XII - XIV. Atti del Convegno Internazionale di Studi, Genova - Venezia, 10 - 14 marzo 2000 / A cura di G. Ortalli - D. Puncuh. Venezia, 2001. P. $257-272$.

Karpov S. P. On the Origin of medieval Tana // STEFANOS. Studia byzantina ac slavica Vladimíro Vavř́nek dedicata. BS, LVI/1. 1995. P. $227-235$.

Laiou-Thomadakis A. E. The Byzantine Economy in the Mediterranean Trade System, Thirteenth - Fifteenth Centuries // DOP, 1980 - 1981, vol. 34 / 35, P. 177 - 222.

Lane F. C. Le Navi di Venezia. Torino, 1983.

Lane F. C. Venice and History. Baltimore, 1966.

Lane F. C. Venice: A Maritime Republic. Baltimore; London, 1973.

Lane F., Mueller R. C. Money and banking in Medieval and Renaissance Venice. Baltimore; London, 1985. Vol.1.

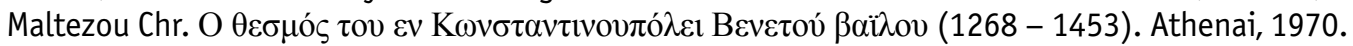

Martin C. A. Venetian Tana // Byzantinische Forschungen, Bd. XI. Amsterdam, 1980.

Melis F. Documenti per la storia economica dei secoli XIII - XVI. Firenze, 1972.

Mueller Reinhold C. The Venetian Money Market; Banks, Panics and the Public Debt, 1200-1500. Baltimore/London: Johns Hopkins Press, 1997.

Nicol D. Byzantium and Venice: a study in diplomatic and cultural relations. Cambridge University Press, Cambridge, 1988.

Nystazopoulou-Pelekides M. Venise et la Mer Noire du XIe au XVe siècle // Thesaurismata. 1970. Vol. 7. P. 15 - 51.

Thiriet F. La Romanie Vénitienne au moyen âge. Paris, 1959.

Urkunden zur alteren Handels- und Staatsgeschichte der Republik Venedig mit besonderer Beziehung auf Byzanz und die Levante om 9. bis zum Ausgang des 15. Jahrh. herausg. von G. L. Fr. Tafel und G. M. Thomas, Vienne 1856-57.

Verlinden Ch. Esclaves et etnographie sur les bords de la Mer Noire (XIIIe et XIVe siècles) // Miscellanea historica in honorem L. van der Essen. Bruxelles - Paris, 1947.

Verlinden Ch. La colonie venetienne de Tana, centre de la traite des esclaves au XIVe et au début du XVe siècle // Studi

in onore di Gino Luzzatto. Milano, 1950, vol. 2, P. 1 - 25.

Verlinden Ch. Le commerce en Mer Noire // XIII Congress International des sciences historiques. Moscou, 1970. 
Verlinden Ch. L'esclavage dans l'Europe médiévale. T. 2: Italie. Colonie italiennes du Levant latin. Empire Byzantin. Gent, 1977.

Vigna A. Codice diplomatico delle colonie tauro-liguri durante la signoria dell'Ufficio di San Giorgio (1453 - 1475) //

ASLSP. Genova, 1868 - 1879. V. VI - VII.

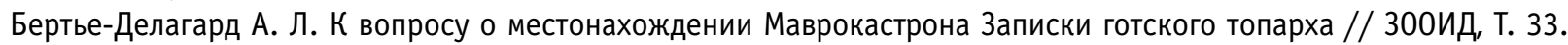
Одесса, 1916. С. 1 - 20.

Брун Ф. К. Etudes sur le commerce au moyen-âge. Histoire du commerce de la mer Noire et des colonies Génoises de la Krimée / Par F. de la Primandaie // З00ИД, Т. 2. Одесса, 1848. С. 709 - 718.

Брун Ф. К. Восточный берег Черного моря по древним периплам и по компасовым картам // 300ИД, Т. 9. Одесса, 1875. С. $410-428$.

Брун Ф. К. Древняя топография некоторых мест Новороссийского края и Бессарабии. Б. г..

Брун Ф. К. Материалы для истории Сугдеи. Одесса, 1871.

Брун Ф. К. 0 поселениях итальянских в Газарии. М., 1872.

Брун Ф. К. Одесское общество истории и древностей, его записки и археологические собрания. 0десса, 1870.

Брун Ф. К. Рецензия на: Обмеление Азовского моря. Приложение к Морскому Сборнику. СПб., 1861 // 300 Д, Т. 5. Одесса, 1863. С. $966-973$.

Брун Ф. К. Черноморские готы и следы долгого их пребывания в Южной России. СПб., 1874.

Брун Ф. К. Черноморье. Одесса, 1879 - 1880. Ч. 1, 2.

Волков М. 0 соперничестве Венеции с Генуей в XIV в. // З00ИД. 1860. Т. 4. С. 151 - 236.

Волков М. Четыре года города Каффы $(1453,1454,1455$ и 1456) // 300ИД, Т. 8. Одесса, 1872. С. 109 - 144.

Григорьев, В. Монеты Джучидов, генуэзцев и Гиреев, битые на Таврическом полуострове и принадлежащие 0бществу // З00ИД, Т. 1. Одесса, 1844. С. $301-314,654$.

Дживелегов А. К. Торговля на Западе в Средние века. СПб., 1904.

Еманов А. Г. Север и Юг в истории коммерции на материалах Каффы XIII - XV вв. Тюмень, 1995. С. 111.

Извлечение из сочинений Вильгельма Гейда «История торговли Востока в средние века (Колонии на северном побережье Черного моря. Конец западных колоний северного побережья Черного моря)». Перевод Л. П. Колли // ИТУАК, №52 (год двадцать восьмой). Симферополь, 1915. С. 68 - 185.

Карпов С. П. Венецианская Тана по актам канцлера Бенедетто Бьянко (1359-60 гг.) // Причерноморье в средние века. Вып. 5. М.; СПб, 2001. С. 9 - 26.

Карпов С. П. Документы по истории венецианской фактории Тана во второй половине XIV в. // Причерноморье в средние века / Под ред. С. П. Карпова. Вып. 1. М., 1991. С. $191-216$.

Карпов С. П. Древнейшие постановления Сената Венецианской республики о навигации в Черном море // Причерноморье в средние века / Под ред. С. П. Карпова. Вып. 4. СПб., 2000. С. 11 - 18.

Карпов С. П. История Трапезундской империи. СПб., 2007.

Карпов С. П. Итальянские морские республики и Южное Причерноморье в XIII - XV вв. М., 1990.

Карпов С. П. Кризис Таны 1343 г. в свете новых источников. // ВВ.1994. Т. 55 (80). Ч. 1. С. 121 - 126.

Карпов С. П. Путями средневековых мореходов: Черноморская навигация Венецианской республики в XIII - XV вв. М., 1994.

Ковалевский М. М. К ранней истории Азова. Венецианская и генуэзская колонии в Тане в XIV веке // Tруды XII Археологического съезда в Харькове, 1902. М., 1905. Т. 2. С. $109-174$.

Ковалевский М. М. 0 русских и других православных рабах в Испании // Юридический вестник. М., 1886. Вып. 2.

C. $238-254$.

Ковалевский М. М. Шестой Археологический съезд в Одессе // Вестник Европы. 1884. Кн. 12. С. 842.

Козубовский Г. А. 0 времени появления Каффинских надчеканок на джучидских монетах // Сугдейский сборник, вып. II. Киев; Судак, 2005. С. 156.

Колли Л. П. Исторические документы о падении Каффы // ИТУАК, №45 (год двадцать пятый). Симферополь, 1911. С. $1-24$.

Колли Л. П. Каффа в период владения Банком св. Георгия // ИТУАК. 1912. Т. 47. С. 75 - 112.

Колли Л. П. Об одном генуэзском барельефе Феодосийского музея (с рисунками) // ИТУАК, №53 (год двадцать девятый). Симферополь, 1916. С. $147-151$.

Колли Л. П. Падение Каффы // ИТУАК, №54 (год тридцать первый). Симферополь, 1918. С. 129 - 171.

Колли Л. П. Хаджи-Гирей хан и его политика (по генуэзским источникам). Взгляд на политические сношения Каффы с татарами в XV веке // ИТУАК, №50 (год двадцать шестой). Симферополь, 1913. С. 99 - 139.

Кочубинский А. Лапидарные надписи XV столетия из Белгорода, что ныне Аккерман // З00ИД, Т. 15.0 десса, 1889. С. $506-547$.

Кулишер И. Н. Эволюция прибыли с капитала в связи с развитием промышленности и торговли в Западной Европе.

Т. 1. СПб., 1906.

Матиева А. Х. История итальянских факторий Северного Причерноморья в рукописях и трудах М. М. Ковалевского

// Причерноморье в средние века / Под ред. С. П. Карпова. Вып. 7. М.; СПб., 2009. С. 238 - 378.

Мурзакевич Н. Донесение об осмотре архива Банка Св. Георгия // 300ИД, Т. 5. Одесса, 1863. С. 982 - 985.

Мурзакевич Н. Медные монеты города Каффы // 300ИД, Т. 4. Одесса, 1860. С. 387 - 388.

Мурзакевич Н. Филипп Карлович Брун // З00ИД, Т. 12. Одесса, 1881. С. $443-446$. 
Луццато Дж. Экономическая история Италии. Античность и средние века. М., 1954.

Опимах О. Г. Коллекция генуэзско-татарских аспров в собрании национального заповедника «София Киевская» // Сугдейский сборник, вып. II. Киев; Судак, 2005. С. 527.

Пономарев А. Л. Денежный рынок Трапезундской империи в XIII - XV вB. // Причерноморье в средние века / Под ред. С. П. Карпова. Вып. З. СПб., Алетейя, 1998. С. 201 - 239.

Пономарев А. Л. Деньги Золотой Орды и Трапезундской империи. Квантитативная нумизматика и процессы средневековой экономики. М., 2002.

Пономарев А. Л. Монетное обращение Золотой Орды в XIV в. (методика анализа) // Причерноморье в средние века / Под ред. С. П. Карпова. Вып. 2. М., 1995. С. 131 - 155.

Пономарев А. Л. Эволюция денежных систем Причерноморья и Балкан в XIII - XV вв. Автореф. дисс...докт.ист. наук. М., 2010.

Прокофьева Н. Д. Акты венецианского нотария в Тане Донато а Мано (1413 - 1419) // Причерноморье в средние века / Под ред. С. П. Карпова. Вып. 4. СПб., 2000. С. 36 - 174.

Разные замечания, касательные до острова Таманя // 300ИД, Т. 10. Одесса, 1877. С. 230 - 234.

Ретовский 0. Ф. Генуэзские надписи, найденные в г. Феодосии в 1894 г // 300ИД, Т. 19. 0десса, 1896. С. 14 - 26.

Ретовский 0. Ф. Генуэзско-татарские монеты (с 1 табл.) // ИТУАК, том 51 (1914 г.). С. 1 - 16.

Ретовский 0. Ф. Генуэзско-татарские монеты (с 6 табл.). ИТУАК, Т. 18 (1906). 1 - 72.

Ретовский 0. Ф. Генуэзско-татарские монеты города Каффы // ИТУАК, №27 (год одиннадцатый). Симферополь, 1897. С. 49 - 104.

Ретовский 0. Ф. Генуэзско-татарские монеты города Каффы // ИтУАК, №29 (год двенадцатый). Симферополь, 1899. C. 1 - 52 .

Ретовский 0. Ф. Генуэзско-татарские монеты города Каффы // ИТУАК, №32 - 33 (год шестнадцатый). Симферополь, 1902. С. 1 - 17.

Ретовский 0. Ф. Генуэзско-татарские монеты города Каффы // ИтУАК, №29 (год двенадцатый). Симферополь, 1899. C. 51.

Талызина А. А. Венецианские нотариальные акты: новые возможности старых источников. // Byzantinoslavica. 1999. Vol. LX/2, P. $459-468$.

Талызина А. А. Венецианский нотарий в Тане Кристофоро Риццо (1411 - 1413) // Причерноморье в средние века / Под ред. С. П. Карпова. Вып. 4. СПб., 2000. С. 19 - 35.

Устав для генуэзских колоний в Черном море, изданный в Генуе в 1449 г. / Латинский текст с переводом и примечаниями; изд. В. Н. Юргевич // З00ИД. Одесса, 1863. Т. V. С. $629-837$.

Федоров-Давыдов Г. А. Денежно-весовые единицы Таны в начале XIV в. (по данным Франческо Пеголотти) // СА. 1958. N 3. С. $65-72$.

Фомичев Н. М. Джучидские монеты из Азова // СА. 1981. № 1. С. 225, 239.

Шестой Археологический съезд в Одессе 1884 // Труды VI Археологического съезда в Одессе. 0десса, 1886. Т. 1. C. $27,65-66$.

Юргевич В. Генуэзская надпись, найденная в Феодосии в 1883 году // 300ИД, Т. 14. 0десса, 1888. С. 24 - 26.

Юргевич В. Генуэзские надписи в Крыму // 300ИД, Т. 5. Одесса, 1863. С. 157 - 177.

Юргевич В. Две генуэзские надписи из Балаклавы // 300ИД, Т. 11. Одесса, 1879. С. 319 - 320.

Юргевич В. Замечания на статью о Генуэзских монетах, помещенную в VIII томе Записок Общества, сделанные итальянским ученым К. Десимони // З00ИД, Т. 8. 0десса, 1872. С. 465 - 471.

Юргевич В. Новые надписи Генуэзские // З00ИД, Т. 7. Одесса, 1868. С. $274-281$.

Юргевич В. 0 монетах Генуэзских, находимых в России // 300ИД, Т. 8. Одесса, 1872. С. 147 - 166.

Юргевич В. Об археологических разысканиях и открытиях в Южной России, предшествовавших учреждению Одесского Общества истории и древностей // З00ИД, Т. 14. Одесса, 1888. С. 27 - 51. 